\title{
DEVELOPMENT AND VALIDATION OF WILLINGNESS TO COMMUNICATE, LANGUAGE USE, AND MOTIVATION QUESTIONNAIRES
}

\author{
Ubaid ULLAH*1 \\ Joseph RAMANAIR ${ }^{2}$ \\ Soubakeavathi RETHINASAMY ${ }^{3}$ \\ 1, 2, ${ }^{3}$ Faculty of Language and Communication \\ University Malaysia Sarawak (UNIMAS) \\ 1Ubaidwahid@gmail.com* \\ ${ }^{2}$ rjoseph@unimas.my \\ ${ }^{3}$ rsouba@unimas.my
}

Manuscript received 17 November 2020

Manuscript accepted 31 May 2021

*Corresponding author

https://doi.org/10.33736/ils.2763.2021

\begin{abstract}
The main goal of modern second language (L2) pedagogy is to engender appropriate communication skills among its learners. Hence, willingness to communicate (WTC) in L2 emerged as an important variable in recent years. Several factors have been found to influence students' L2 WTC directly or indirectly. For this purpose, many scales and questionnaires have been developed so far to examine the factors influencing WTC among L2 students. However, a comprehensive questionnaire on WTC inside ESL classroom is still lacking. Likewise, WTC in relation to language use and motivational orientations in a single study has yet to be investigated. Thus, this study was aimed to develop and validate questionnaires on WTC, language use and motivational orientations. For this purpose, a five-phase model was used. After an extensive literature review, questionnaires on WTC, language use and motivational orientations were framed. Operational definitions of the three constructs were established and the items of the questionnaires were finalised. Two experts in the field of applied linguistics determined the content validity of the questionnaires. At the end, the questionnaires were piloted on 50 undergraduates and 10 ESL teachers. The results revealed that all the instruments were valid and highly reliable.
\end{abstract}

Keywords: Willingness to communicate (WTC); language use; motivational orientations; validity; reliability 


\section{Introduction}

English has become an international language of communication as a result of colonialism and subsequently the processes of globalisation (Rassool, 2013). Kachru and Nelson (2006) maintained that English is no more a language of its native speakers since it is, "the most widely taught and spoken language that the world has ever known" (p. 9). This explains why English has been given the status of second language (ESL) (Graddol, 1997) among many non-native speakers who use it in their daily lives. Thus, the main objective of second language (L2) pedagogy should be to promote authentic communication skills among its learners (de Saint Léger \& Storch, 2009; Maclntyre et al., 2011). Moreover, Maclntyre et al. (1998) claimed that "a proper objective for L2 education is to create willingness to communicate (WTC)" among L2 learners (p. 547). The concept of WTC originated from McCroskey and Baer (1985) in the first language (L1). From the empirical research on WTC in L1 context, Maclntyre et al. (1998) introduced WTC in L2. WTC in L2 is defined as "readiness to enter into discourse at a particular time with a specific individual" (Maclntyre et al., 1998, p. 547).

Various types of factors have been found to influence learners' WTC in L2 learning (Mystkowska-Wiertelak, 2018; Riasati \& Rahimi, 2018). These factors include international posture (Yashima, 2002; Yashima et al., 2004), gender and age (Maclntyre et al., 2002), motivation (Hashimoto, 2002; Maclntyre et al., 2001; Peng \& Woodrow, 2010), and self-confidence (Baker \& Maclntyre, 2003; Maclntyre, 1994). The WTC construct entails both trait and state propensities (Cao, 2014; Dörnyei, 2005). Thus, most previous research examined WTC as either a state variable that changes according to situation and person, or a trait variable that is enduring and remains the same in all situations (Cao \& Philp, 2006; Maclntyre et al., 1999;). However, the quantitative research investigating learner's WTC with regard to classroom multiple situations (e.g., at individual level, in pairs, in small groups and in the whole class interaction), in different types of activities (e.g., role-play, presentation, discussion, with the same and opposite gender), classroom physical conditions (e.g., seating position, in front, in middle, and at the back of the class) are yet to be examined. Secondly, WTC has been widely investigated in relation to motivation, anxiety, perceived communication competence, but most studies seems not to emphasise on WTC in relation to language use (Cetinkaya 2005; Hashimoto, 2002; Kim 2004; Maclntyre et al. 1999; Yashima, 2002). Thirdly, WTC in relation to motivational orientation has rarely been investigated in the current context of the study. Fourthly, WTC construct from teachers' perspective has yet to be examined. Thus, the main aim of the current study is to develop and validate the four questionnaires i.e. on WTC in ESL context for students, teachers' views about the learners' WTC inside classroom, learners' language use outside classroom, and motivational orientations to learn English of Pakistani undergraduates.

Pakistan is a multilingual country with almost seventy-four different languages (Islam et al., 2013, Panhwar et al., 2017; Shamim, 2011). Including this, English used as the official language in public and private sectors (Ali, 2017; Shamim, 2011; Tamim, 2014). Moreover, Pakistani students learn English as a compulsory subject from primary to university levels (Shamim, 2011; Bukahri et al., 2015). 
English is the gateway to high paid jobs, it is the language of elites, military, education, corporate sector, media and education in Pakistan (Shamim, 2011). However, Pakistani undergraduates' lack in English communication skills (Nosheen et al., 2020). In concurrence, Ali et al. (2020) asserted that Pakistani students are hesitant when communicating in English.

The current pilot study is the part of the main research doctoral project in which the researcher will investigate WTC inside the classroom in relation to language use outside the classroom, and motivation to learn English. This study aims to develop and validate four questionnaires i.e. WTC for undergraduates, language use, motivational orientations, and teachers' views about their undergraduates' WTC.

The first part of this paper contains the introduction and aim of the study followed by previous literature on instruments development, methodology, a fivephased model of instrument development data collection procedure, reliability of the instruments, results and discussion, and conclusion.

\section{Related Literature}

\section{Previous Instruments Developed on WTC, Language Use, and Motivational Orientations}

In order to examine L2 WTC, various questionnaires have been developed out of which most of the research has been based on the scale developed by McCroskey and Baer (1985) in WTC L1 context (Ali, 2017; Asmali, 2016; Hashimoto, 2002; MacIntyre \& Doucette, 2010; Mahdi, 2014; Yashima et al., 2004). The McCroskey and Baer (1985) WTC scale consists of 20 items covering the major areas like "talking with friends, acquaintances, strangers in public, large meetings, and small groups" (p. 10). Syed (2016) stated that this questionnaire is not applicable in Asian ESL context for several reasons. First, the questionnaire has been designed to measure L1 WTC. Second, situations mentioned in the questionnaire are uncommon in ESL countries like Pakistan. For example, items such as "talking with an acquaintance in an elevator, speaking in public to a group of strangers, talking with a garbage collector" (p. 10). Third, the items represent ordinary life situations rather than a classroom situation (Peng, 2013). Moreover, Maclntyre et al. (2001) developed an L2 WTC scale on both inside and outside classroom situations. This scale measures L2 WTC in the four areas, namely, comprehension, writing, reading, and speaking. However, the items of this questionnaire are greatly influenced by the WTC in L1 scale and focus on situations less likely to happen in a language classroom (Weaver, 2005).

Using Rasch model, Weaver (2005) developed a speaking and writing 34item WCT scale in Japanese EFL classroom context. The psychometric usefulness is supported by the results of the scale. However, in this scale many items are ambiguous as the interlocutors are not specified such as "[i]nterview someone in English asking questions from the textbook" (Weaver, 2005, p. 415). The word "someone" may confuse the respondents, it may be inferred as classmates or teachers which may influence the measure of the scale (Peng, 2013). Khatib and 
Nourzadeh (2014) developed and validated a 27-item instructional WTC (IWTC) questionnaire in EFL settings. After the Confirmatory Factor Analysis (CFA) and Exploratory Factor Analysis (EFA), six factors for IWTC were found. The author ignored WTC in small groups, pairs, individually, and whole class interaction during different kinds of activities, namely, role play, discussion, and presentation, preparedness, gender, and classroom seating position. Riasati and Rahimi (2018) developed a questionnaire after they conducted literature review in the Iranian EFL classroom setting, but the validity and reliability of this questionnaire were not reported. The researchers found that most of the questionnaires/scales are developed in either L1 or EFL context. After the extensive literature review, the authors could not find a comprehensive questionnaire on WTC in ESL classroom settings. Thus, a detailed questionnaire including 14 different classroom situations in ESL WTC for students and the ESL teachers' views about their students' WTC were established.

Similarly, several questionnaires were developed and validated on the domains of language use. Nofal and Dweik (2011) developed and validated a questionnaire using eight domains, namely, emotional self-expressions, different situations, religion, media, workplace, school, neighbourhood, and home/family. The questionnaire contained items such as language use with "grandmothers" and "grandfathers" which may confuse the respondents. The respondents may not be able to differentiate whether the author is asking regarding paternal grandfather or paternal grandmother. Moreover, the author has ignored the important domain of social media. A questionnaire on religion, friendship and family domains was developed by Leo and Abdullah (2013), but the validity and reliability of this questionnaire was not reported. Qawar (2014) developed and validated a questionnaire on seven different domains including governmental offices, emotional self-expression, media, workplace, place of worship, home and relatives, and neighbourhood. However, the author overlooked the transactional, educational, and social media domains. Anjum et al. (2016) developed and validated a questionnaire in Mankiyali language (a minority language) in Pakistan. The domains included friendship, family and neighbourhood, and religion. However, the authors did not add the transactional, social media, educational, and mass media domains, which are the focus of the current study. The current questionnaire on language use encompasses all the important domains of language use (family, neighbourhood and friendship, educational, religion, transactional, mass media and social media) encountered by an individual in daily life interactions.

Moreover, various scales on integrative and instrumental motivational orientations have been developed, adapted and validated. The most widely used scale for measuring motivation is Gardner $(1985,2004)$ Attitude and Motivation Test Battery (AMTB). The scale contains the following constructs including: language anxiety, instrumental orientation, motivation, attitudes towards the learning situation, and integrativeness. However, in AMTB, both integrative and instrumental orientations comprise only four items each. Nikitina et al. (2016) developed and validated a questionnaire on language learning motivation. After the CFA and EFA, four dimensions of L2 motivation were formed, namely, effort, commitment, integrative orientation, and instrumental orientation. The questionnaire consisted of 
16 items out of which integrative and instrumental orientations comprised five items each. Other questionnaires on integrative and instrumental orientations were developed by Vaezi (2008) and Muftah and Rafik-Galea (2013), but the authors neither reported validity nor reliability of their instruments. In contrast, to cover a more holistic picture of integrative and instrumental motivational orientations, the current questionnaire contains 31 items including 15 items for integrative orientation and 16 items for instrumental orientation.

\section{Methodology}

\section{Process for Developing the Instruments}

A five-phase model established for the questionnaire development process by Meerah et al. (2012) was used (see Figure 1).

\section{Figure 1}

Five-Phase Model for the Development of Scale/Questionnaire

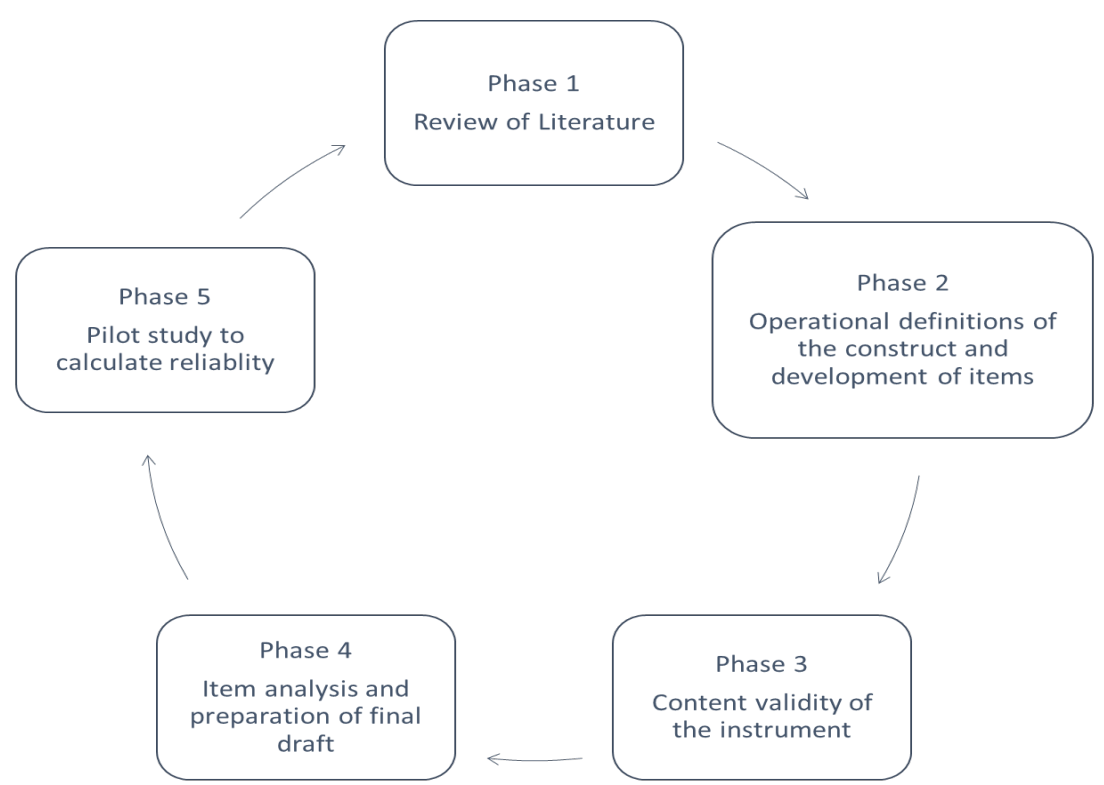

Note: Reprinted from "Developing an instrument to measure research skills", by T. S. Meerah et al. (2012), Procedia-Social and Behavioral Sciences, 60, 630-636.

\section{Phase 1}

In phase one, a comprehensive literature review was done. It was found that different scales or questionnaires were previously developed on the three constructs, that is, WTC, language use, and motivational orientations. However, these questionnaires have some weaknesses and gaps. For example, the scales on WTC were developed either in L1 or EFL context. The focus of some of the WTC questionnaires was on ordinary life situations rather than classroom settings. Furthermore, the researchers could not find a questionnaire on teachers' views 
about their students' WTC. Moreover, questionnaires on the domains of language use lacked certain important domains of everyday life interactions. In addition, questionnaires on integrative and instrumental motivational orientations contained less items and some of the questionnaires' validity and reliability was not reported.

\section{Phase 2}

In phase two, operational definitions of the three constructs were formed and the items development process was undertaken. The operational definitions of the constructs are as follows:

1) WTC inside classroom: An individual's volition to speak English with his/her peers in different situations in class.

2) Domain Language Use: The ability to speak an appropriate language in a specific communicative setting outside classroom.

3) Integrative motivational orientation: An individual's desire to learn English language to understand English culture, art, food, movie etc.

4) Instrumental motivational orientation: An individual's desire to learn English for practical purposes such as job, traveling, study etc.

The items of an instrument should be attractive, concise, unambiguous, and related to the study objectives (Zikmund et al., 2003). Items were adapted from previously developed questionnaires on WTC, language use and motivational orientations. For example, for WTC questionnaire, items like "volunteering to speak individually in class" was modified to "I am willing to speak in English individually in class". Due to the unavailability of questionnaires on teachers' views about students' WTC inside classroom, the same items were modified to examine teachers' perspectives. For instance, "I am willing to speak in English individually in class" changed to "my students are willing to speak in English individually in class". Likewise, for language use outside classroom, the items like "what language do you speak with your parents" changed to "how often do you speak these languages with your father" by giving different options of languages like English, Urdu, Pashto, and other languages on a frequency scale. Similarly, the items on integrative and instrumental motivational orientations were modified. For example, the item "Studying English enables me to appreciate other country's arts and literature" was modified to "I learn English to understand English art and literature". Thus, an item pool of more than one hundred items for each of the constructs was formed.

\section{Phase 3}

In phase three, content validity of the WTC, language use, and motivational orientations questionnaires were determined. In content validity, experts' opinion is the extensively used method (Brown, 1983, cited in Pamuk et al., 2015). Gay et al. (2011) argued that experts' judgment is the suitable way to determine the content validity of a questionnaire. Moreover, Brown (1983) asserted that experts' review is ample to determine that the questionnaire has content validity. At least two experts are required for content validity of an instrument (Gable \& Wolf, 2012). The final 
choice of the items should be based on the experience and qualification of the experts in the field (Davis, 1992). In this present study, two experts from the field of applied linguistics were involved in the validation process of the questionnaires. The experts reduced the number of items of WTC both students and teachers' views about their students' WTC to 80 items each, domain of language use questionnaire to 50 items, and the integrative instrumental motivational orientation questionnaire to 31 items. Moreover, the experts examined and validated the wording, the appropriateness, and structure of the instruments.

\section{Phase 4}

In phase four, all items were again examined by the experts and they suggested a five-point Likert scale ranges from Strongly Disagree to Strongly Agree for WTC and motivational orientation questionnaires, and a five-point frequency scale that ranges from Not Applicable to Frequently for language questionnaire was formed. Thus, the final drafts of all the questionnaires were established.

\section{Phase 5}

In the last phase, the questionnaires were piloted to 50 undergraduates and $10 \mathrm{ESL}$ teachers. The reliability results of the questionnaires are reported in the subsequent section.

\section{Participants}

The pilot participants were 50 undergraduates and $10 \mathrm{ESL}$ university teachers. The undergraduates were enrolled in the third semester of the Bachelor of Science (BS)programme at the National University of Modern Languages (NUML) Pakistan. Researchers suggested that a pilot study sample should range from 10 to 30 participants as the representative sample for the main study in survey research (Hill, 1998; Isaac \& Michael, 1995; Johanson \& Brooks, 2010; Machin et al., 2018). Connelly (2008) maintained that a pilot study sample should be $10 \%$ of the sample projected for the larger parent study. The sample size of the main study was 420 undergraduates, and $35 \mathrm{ESL}$ teachers taken from seven different universities, each cluster had 60 students and five ESL teachers. In each university 6000 to 7000 students are enrolled in BS programmes.

\section{Data Collection Procedure}

The data were collected in two phases from undergraduate students in two days. On the first day, a group of 25 students was given a consent form to complete as an indication of the participants' agreement in this study. Prior to signing the consent form by participants, the researcher explained the aim of the study. Next, the three questionnaires (WTC inside classroom, Language use outside classroom and Motivation to learn English) were administered. On the second day, the same process was repeated with another group of 25 undergraduates. Both phases for undergraduates were conducted during English as compulsory subject class with the 
permission of the Head of Department and class teachers in the presence of the researcher.

During the data collection, some of the undergraduates were confused about the meaning of "praying" in item number 29 (how often do you use these languages when praying) in the religion domain in language use questionnaire. The reason is that the Urdu word "Namaz" was not written in parentheses for "praying" which means worship. Praying could be taken either supplication or worship in Pakistani context. This problem was addressed by including the word "Namaz" in the parenthesis in the revised version of the questionnaire (how often do you use these languages when praying (Namaz). The undergraduates took 40-45 minutes to complete the questionnaires. After cleaning and tabulating of the undergraduates' data, out of 50 questionnaires, three were discarded due to incomplete responses, 47 questionnaires were analysed.

Next, a set of questionnaires was distributed among 10 teachers. The same procedure was repeated. The teachers were asked to respond to the questionnaire on their views about their undergraduates' WTC inside classroom. The teachers took 10-15 minutes to respond to the questionnaire. To sum up, all phases of the data collection took place in a friendly environment and the pilot participants were able to respond to the questions.

\section{Reliability of the Instruments}

Reliability concerns with the stability in results of an instrument (Carmines \& Zeller, 1979). An instrument is considered reliable if it is repeatedly tested under constant conditions and gives the same results (Moser \& Kalton, 1985). A scale has high internal consistency among its items if the items are hanging together while measuring the same construct (Robinson, 2010). Moreover, Taherdoost (2016) argued that the most commonly used measure for internal consistency is Cronbach's Alpha. According to George and Mallery (2003) to determine the reliability of a research instrument (i.e. questionnaire) on Cronbach's alpha, the following are rules of thumb: "_> .9 - Excellent, _ .8 - Good, _> .7 - Acceptable, _> .6 Questionable, _ $>.5$ - Poor, and_<.5 - Unacceptable" (p. 231). In concurrence, Hinton et al. (2004) suggested proper cut-off points for the reliability of a research tool, which includes ( 0.50 and below) low reliability, (0.50 to 0.7$)$ moderate reliability, (0.70 to 0.90$)$ high reliability, (0.90 and above) excellent reliability.

\section{Results and Discussion}

The main aim of the current study is to develop and validate questionnaires on WTC in ESL context both for students and teachers' views about their students' WTC inside classroom, language use outside classroom, and motivation to learn English. To determine the reliability of the instruments, the data were analysed through Cronbach's alpha using SPSS version 25. This article only presents the results of one cluster of respondents. 


\section{Undergraduates' WTC Questionnaire}

Table 1

Reliability of Questionnaire on Undergraduates' WTC in English Inside Classroom

\begin{tabular}{|c|c|c|c|c|}
\hline & WTC Subscales & $\begin{array}{l}\text { Number } \\
\text { of Items }\end{array}$ & $\begin{array}{l}\text { Cronbach's } \\
\text { Alpha }\end{array}$ & Reliability \\
\hline 1 & General Grouping & 3 & .822 & Good \\
\hline 2 & Grouping and Activity & 6 & .806 & Good \\
\hline 3 & Grouping and Gender & 4 & .882 & Good \\
\hline 4 & Grouping, Activity and Gender & 12 & .896 & Good \\
\hline 5 & Grouping and Preparedness & 3 & .782 & Acceptable \\
\hline 6 & Grouping, Activity, and Preparedness & 8 & .874 & Good \\
\hline 7 & $\begin{array}{l}\text { Seating Position (in front of the class) } \\
\text { Grouping }\end{array}$ & 3 & .810 & Good \\
\hline 8 & $\begin{array}{l}\text { Seating Position (in front of the class) } \\
\text { Grouping and activity }\end{array}$ & 8 & .872 & Good \\
\hline 9 & $\begin{array}{l}\text { Seating Position (in the middle of class) } \\
\text { grouping }\end{array}$ & 3 & .776 & Acceptable \\
\hline 10 & $\begin{array}{l}\text { Seating Position (in the middle of class) } \\
\text { grouping and activity }\end{array}$ & 8 & .868 & Good \\
\hline 11 & $\begin{array}{l}\text { Seating position (at the back of the } \\
\text { class) grouping }\end{array}$ & 3 & .808 & Good \\
\hline 12 & $\begin{array}{l}\text { Seating position (at the back of the } \\
\text { class) grouping and activity }\end{array}$ & 8 & .904 & Excellent \\
\hline 13 & Whole class and grouping & 3 & .815 & Good \\
\hline 14 & Whole class grouping and activity & 8 & .926 & Excellent \\
\hline 1 & WTC Scale (all items) & 80 & .978 & Excellent \\
\hline
\end{tabular}

Table 1 shows the reliability of undergraduates' WTC inside classroom questionnaire. The questionnaire consisted of 14 subscales and the main WTC scale contains 80 items in total. Results show that all of the WTC subscales and WTC scale were highly reliable. The overall reliability of is $\alpha=.978$, which higher than .9 showing excellent reliability.The findings match Baker and Maclntyre (2000) WTC questionnaire that had alpha value .97. Whereas Weaver (2005) WTC had $\alpha=.93$ and considered as highly reliable instrument. On the other hand, the Khatib and Nourzadeh (2014) instructional WTC questionnaire's Cronbach's alpha was $\alpha=.92$ which show "high internal consistency" (p. 10) among the items of the questionnaire. Moreover, Riasati and Rahimi (2018) developed a WTC inside classroom questionnaire in Iranian context, but the validity and reliability of the questionnaire was not reported. Thus, the current study questionnaire on undergraduates' WTC was found highly reliable compare to previous questionnaires. 


\section{Language Use Questionnaire}

\section{Table 2}

Reliability of Questionnaire on Undergraduates' Language Use Outside Classroom according to Domain and All Items

\begin{tabular}{llccc}
\hline Domain & $\begin{array}{c}\text { Number } \\
\text { of Items }\end{array}$ & $\begin{array}{c}\text { Cronbach's } \\
\text { Alpha }\end{array}$ & Reliability \\
\hline 1 & Family Domain & 60 & .898 & Good \\
2 & Neighbourhood and Friendship Domain & 12 & .786 & Acceptable \\
3 & Educational Domain & 12 & .722 & Acceptable \\
4 & Religious Domain & 12 & .825 & Good \\
5 & Transactional Domain & 21 & .837 & Good \\
6 & Mass Media Domain & 24 & .743 & Acceptable \\
7 & Social Media Domain & 9 & .761 & Acceptable \\
\hline & All items & 150 & .910 & Excellent \\
\hline
\end{tabular}

Table 2 shows domain-wise reliability of undergraduates' language use outside classroom questionnaire (i.e. family, neighbourhood and friendship, educational, religious, transection, mass media, and social media). The reliability of all 150 items is $\alpha=.910$. The reliability of all the items is . 9 and above showing excellent reliability. Overall, the subscales (domains) and all items of the language use questionnaire were found to be highly reliable.

The findings are in line with Nofal and Dweik (2011) who developed and validated questionnaire comprised eight domains of language use applying Cronbach's alpha. The alpha value of the questionnaire was .838. Ajnum et al. (2016) developed and validated a questionnaire including the domains of friendship, family and neighbourhood, and religion with alpha value .84. Conversely, Qawar (2014) developed a questionnaire on seven domains, but reliability of the questionnaire was not reported.

\section{Motivational Orientations Questionnaire}

Table 3

Reliability of Undergraduates' Motivational Orientation to Learn English Questionnaire

\begin{tabular}{llccc}
\hline Motivational Orientation & $\begin{array}{r}\text { Number } \\
\text { of Items }\end{array}$ & $\begin{array}{c}\text { Cronbach's } \\
\text { Alpha }\end{array}$ & Reliability \\
\hline 1 & Integrative Motivation & 15 & .850 & Good \\
2 & Instrumental Motivation & 16 & .915 & Excellent \\
\hline 3 & All items & 31 & .925 & Excellent \\
\hline
\end{tabular}

Table 3 shows the high reliability of undergraduates' motivational orientations to learn English questionnaire. The integrative motivation of 15 items and instrumental motivation of 16 items demonstrate alpha values .850 and .915 show good and excellent reliability respectively. The reliability of all items is $\alpha=.925$ represent excellent reliability. 
The findings are in line with Nikitina et al. (2016) who found that the reliability of the integrative and instrumental motivations were .754 and .831 respectively. The authors claimed that the both of the motivational scales had good reliability. While the Al-Ta'ani (2018) questionnaire's overall reliability of integrative and instrumental motivation was $\alpha=.78$. Thus, the questionnaire of the current study is highly reliable.

\section{Teachers' Views about their Students' WTC Questionnaire}

\section{Table 5}

Reliability of Teacher's View about their Undergraduates' WTC Inside Classroom Questionnaire

\begin{tabular}{|c|c|c|c|c|}
\hline & Subscales & $\begin{array}{l}\text { Number of } \\
\text { Items }\end{array}$ & $\begin{array}{l}\text { Cronbach's } \\
\text { Alpha }\end{array}$ & Reliability \\
\hline 1 & General Grouping & 3 & .851 & Good \\
\hline 2 & Grouping and Activity & 6 & .875 & Good \\
\hline 3 & Grouping and Gender & 4 & .721 & Acceptable \\
\hline 4 & Grouping, Activity and Gender & 12 & .772 & Acceptable \\
\hline 5 & Grouping and Preparedness & 3 & .739 & Acceptable \\
\hline 6 & Grouping, Activity, and Preparedness & 8 & .900 & Excellent \\
\hline 7 & $\begin{array}{l}\text { Seating Position (in front of the class) } \\
\text { Grouping }\end{array}$ & 3 & .717 & Acceptable \\
\hline 8 & $\begin{array}{l}\text { Seating Position (in front of the class) } \\
\text { Grouping and activity }\end{array}$ & 8 & .922 & Excellent \\
\hline 9 & $\begin{array}{l}\text { Seating Position (in the middle of class) } \\
\text { grouping }\end{array}$ & 3 & .908 & Excellent \\
\hline 10 & $\begin{array}{l}\text { Seating Position (in the middle of class) } \\
\text { grouping and activity }\end{array}$ & 8 & .943 & Excellent \\
\hline 11 & $\begin{array}{l}\text { Seating position (at the back of the class) } \\
\text { grouping }\end{array}$ & 3 & .887 & Good \\
\hline 12 & $\begin{array}{l}\text { Seating position (at the back of the class) } \\
\text { grouping and activity }\end{array}$ & 8 & .756 & Acceptable \\
\hline 13 & Whole class and grouping & 3 & .842 & Good \\
\hline 14 & Whole class grouping and activity & 8 & .826 & Good \\
\hline & $\begin{array}{l}\text { Teachers' views about their students' } \\
\text { WTC (all items) }\end{array}$ & 80 & .967 & Excellent \\
\hline
\end{tabular}

Table 5 show the reliability of teacher's views about their undergraduates' WTC inside classroom questionnaire, comprising five subscales. The 80 items show excellent reliability which is $\alpha=.967$. Overall, the teachers' views about their students' WTC scale is highly reliable.

As mentioned earlier the previous studies overlooked the teachers' views about their students' WTC. Therefore, the researcher modified items from undergraduates' WTC questionnaire. 


\section{Conclusion}

This study was aimed to develop and validate questionnaires on WTC, language use and motivational orientations and teachers' views about their undergraduates" WTC. The results revealed that all of the four questionnaires were highly reliable. The findings of the study are important because it enabled the researcher to clarify all the ambiguities related to the data collection that might occur in the actual study. Also, it familiarised the researcher with the actual data collection process. The main purpose for conducting the pilot study is to improve efficiency and quality of the actual study and to increase the experience of the researcher (In, 2017). Further Kraemer et al. (2006) maintained that pilot study can help to detect unforeseen problems that may interrupt the flow and quality of main study. Furthermore, this study developed and validated the instruments which can be used for the main study. The validation process of the instruments will be helpful for future researchers. This study is vital because it informed the researcher about the adequacy of the research tools, the feasibility of the main study, and finance required for the main study. Moreover, it also helped in convincing the stakeholders that the main study is worth supporting. The theoretical implications of this study lied under the sociocultural theory. Sociocultural theory claimed that second language learning occurs through mediation and social interaction because language learning is sociocultural phenomenon (Lantolf, 2000). Thus, the main study is intended to expand sociocultural theory to see participants' level WTC in English in different social interactions inside classroom. The present study has some limitations. First, the data were collected from one out of the seven clusters of the main study. It is recommended that future research to conduct similar research with a larger pool of respondent clusters. Second, the researcher employed only Cronbach's Alpha to calculate the reliability of the questionnaires. Future researchers may apply other reliability techniques such as test re-test technique, Kuder-Richardson technique. Third, the questionnaires were modified and validated according to the Pakistani context and objectives of the present study. Future researchers can further modify and validate the same questionnaires according to the context and objectives of their study.

\section{References}

Ali, M. (2017). Investigating Pakistani university students' level of willingness to communicate (WTC) in English as a foreign language: A case study of students from the Shah Abdul Latif University, Khairpur, Sindh (SALU) [Unpublished doctoral dissertation]. Northumbria University.

Ali, M. M., Khizar, N. U., Yaqub, H., Afzaal, J., \& Shahid, A. (2020). Investigating Speaking Skills Problems of Pakistani Learners in ESL Context. International Journal of Applied Linguistics and English Literature, 9(4), 62-70.

Al-Ta'ani, M. H. (2018). Integrative and instrumental motivations for learning English as a university requirement among undergraduate students at Al-Jazeera University, Dubai. International Journal of Learning and Development, 8(4), 89-105. https://doi.org/10.5296/ijld.v8i4.13940 
Anjum, U., Khan, Q., \& Gulzar, A. (2016). Translation, cultural adaptation and cross language validation of domains of language use patterns. Journal of Asian Civilizations, 39(2), 1-25.

Asmali, M. (2016). Willingness to communicate of foreign language learners in Turkish context. Procedia-Social and Behavioral Sciences, 232, 188-195. https://doi.org/10.1016/j.sbspro.2016.10.044

Baker, S. C., \& Maclntyre, P. D. (2000). The role of gender and immersion in communication and second language orientations. Language learning, 50(2), 311-341. https://doi.org/10.1111/0023-8333.00119

Baker, S. C., \& Maclntyre, P. D. (2003). The role of gender and immersion in communication and second language orientations. Language learning, 53(S1), 65-96.

Brown, F. G. (1983). Principles of educational and psychological testing. Wadsworth Pub Co.

Bukhari, S. F., Cheng, X., \& Khan, S. A. (2015). Willingness to Communicate in English as a Second Language: A Case Study of Pakistani Undergraduates. Journal of Education and Practice, 6(29), 39-44.

Cao, Y. (2014). A sociocognitive perspective on second language classroom willingness to communicate. TESOL Quarterly, 48(4), 789-814. https://doi.org/10.1002/tesq.155

Cao, Y., \& Philp, J. (2006). Interactional context and willingness to communicate: A comparison of behavior in whole class, group and dyadic interaction. System, 34(4), 480-493. https://doi.org/10.1016/j.system.2006.05.002

Carmines, E. G., \& Zeller, R. A. (1979). Reliability and validity assessment. Sage Publications.

Cetinkaya, Y. B. (2005). Turkish college students'willingness to communicate in English as a foreign language [Unpublished Doctoral Dissertation] Columbus: Ohio State University.

Connelly, L. M. (2008). Pilot studies. Medsurg Nursing, 17(6), 411-412.

Davis, L. L. (1992). Instrument review: Getting the most from a panel of experts. Applied Nursing Research, 5(4), 194-197. https://doi.org/10.1016/S08971897(05)80008-4

de Saint Léger, D., \& Storch, N. (2009). Learners' perceptions and attitudes: Implications for willingness to communicate in an L2 classroom. System, 37(2), 269-285. https://doi.org/10.1016/j.system.2009.01.001

Dörnyei, Z. (2005). The psychology of the language learner: Individual differences in second language acquisition. Lawrence Erlbaum.

Gable, R. K., \& Wolf, M. B. (2012). Instrument development in the affective domain: Measuring attitudes and values in corporate and school settings (Vol. 36). Springer Science \& Business Media.

Gardner, R. C. (1985). Social psychology and second language learning: The role of attitudes and motivation. Edward Arnold.

Gardner, R. C. (2004). Attitude/motivation test battery: International AMTB research project. The University of Western Ontario. http://hyxy.nankai.edu.cn/jingpinke/buchongyuedu/Motivation\%20measur ement-AMTB.pdf 
Gay, L., Mills, G., \& Airasian, P. (2011). Educational research: Competencies for analysis and applications (10th ed.). Pearson.

George, D., \& Mallery, P. (2003). Reliability analysis. SPSS for Windows step by step: A simple guide and reference. 11.0 update (4th ed.). Allyn \& Bacon.

Graddol, D. (1997). The future of English? A guide to forecasting the popularity of the English language in the 21st century. British Council.

Hashimoto, Y. (2002). Motivation and willingness to communicate as predictors of reported L2 use: The Japanese ESL context. Second Language Studies, 20(2), 29-70.

Hill, R. (1998). What sample size is "enough" in internet survey research? Interpersonal Computing and Technology: An Electronic Journal for the 21st century, 6(3-4), 1-12.

Hinton, P. R., Brownlow, C., McMurray, I., Cozens, B. (2004) SPSS Explained. Routledge. https://doi.org/10.4324/9780203642597

Isaac, S., \& Michael, W. B. (1995). Handbook in research and evaluation: A collection of principles, methods, and strategies useful in the planning, design, and evaluation of studies in education and the behavioral sciences (3 ed.). EdITS.

Islam, M., Lamb, M., \& Chambers, G. (2013). The L2 motivational self system and national interest: A Pakistani perspective. System, 41(2), 231-244.

Jenkins, J. (2007). English as a lingua franca: Attitude and identity. Oxford University Press.

Johanson, G. A., \& Brooks, G. P. (2010). Initial scale development: Sample size for pilot studies. Educational and Psychological Measurement, 70(3), 394-400. https://doi.org/10.1177\%2F0013164409355692

Kachru, Y., \& Nelson, C. L. (2006). World Englishes in Asian contexts. Hong Kong University Press.

Khatib, M., \& Nourzadeh, S. (2014). Development and validation of an instructional willingness to communicate questionnaire. Journal of Multilingual and Multicultural Development, 36(3), 266-283. https://doi.org/10.1080/01434632.2014.914523

Kim, S. J. (2004). Exploring willingness to communicate (WTC) in English among Korean EFL (English as a foreign language) students in Korea: WTC as a predictor of success in second language acquisition [Unpublished Doctoral Dissertation] Columbus: Ohio State University.

Kraemer, H. C., Mintz, J., Noda, A., Tinklenberg, J., \& Yesavage, J. A. (2006). Caution regarding the use of pilot studies to guide power calculations for study proposals. Archives of general psychiatry, 63(5), 484-489.

Lantolf, J. (2000). Second language learning as a mediated process. Language Teaching, 33(2), 79-96. doi:10.1017/S0261444800015329

Leo, A. R., \& Abdullah, A. N. (2013). Language choice and use of Malaysian Tamil Christian youths: A survey. Frontiers of Language and Teaching, 4, 149-166.

Machin, D., Campbell, M. J., Tan, S. B., \& Tan, S. H. (2018). Sample sizes for clinical, laboratory and epidemiology studies. (4th ed.). John Wiley \& Sons.

MacIntyre, P. D. (1994). Variables underlying willingness to communicate: A causal analysis. Communication Research Reports, 11(2), 135-142. https://doi.org/10.1080/08824099409359951 
Macintyre, P. D., \& Doucette, J. (2010). Willingness to communicate and action control. System, 38(2), 161-171. https://doi.org/10.1016/j.system.2009.12.013

Maclntyre, P. D., Babin, P. A., \& Clément, R. (1999). Willingness to communicate: Antecedents \& consequences. Communication Quarterly, 47(2), 215-229. https://doi.org/10.1080/01463379909370135

Maclntyre, P. D., Burns, C., \& Jessome, A. (2011). Ambivalence about communicating in a second language: A qualitative study of French immersion students' willingness to communicate. The Modern Language Journal, 95(1), 81-96. https://doi.org/10.1111/j.1540-4781.2010.01141.x

Maclntyre, P. D., Clément, R., Dörnyei, Z., \& Noels, K. A. (1998). Conceptualizing willingness to communicate in a $\mathrm{L} 2$ : A situational model of $\mathrm{L} 2$ confidence and affiliation. The Modern Language Journal, 82(4), 545-562. https://doi.org/10.1111/j.1540-4781.1998.tb05543.x

Macintyre, P. D., Baker, S. C., Clement, R., \& Donovan, L. A. (2003). Sex and age effects on willingness to communicate, anxiety, perceived competence, and L2 motivation among junior high school French immersion students. Language Learning: A Journal of Research in Language Studies, 53(S1), $137-$ 166. https://doi.org/10.1111/1467-9922.00226

MacIntyre, P., Baker, S., Clément, R., \& Conrod, S. (2001). Willingness to communicate, social support, and language-learning orientations of immersion students. Studies in Second Language Acquisition, 23(3), 369-388. https://doi.org/10.1017/S0272263101003035

Mahdi, D. A. (2014). Willingness to communicate in English: A case study of EFL students at King Khalid University. English Language Teaching, 7(7), 17-25. https://doi.org/10.5539/elt.v7n7p17

McCroskey, J. C., \& Baer, J. E. (1985, November). Willingness to communicate and its measurement. [Paper presentation]. Speech Communication Association Convention, Denver, CO.

Meerah, T. S. M., Osman, K., Zakaria, E., Ikhsan, Z. H., Krish, P., Lian, D. K. C., \& Mahmod, D. (2012). Developing an instrument to measure research skills. Procedia-Social and Behavioral Sciences, 60, 630-636.

Moser, C., \& Kalton, G. (1985). Survey methods in social investigation. Gower.

Muftah, M., \& Rafik-Galea, S. (2013). Language learning motivation among Malaysian pre-university students. English Language Teaching, 6(3), 92-103. https://doi.org/10.5539/elt.v6n3p92

Mystkowska-Wiertelak, A. (2018). Fluctuations in willingness to communicate during a semester: A case study. The Language Learning Journal, 1, 1-12. https://doi.org/10.1080/09571736.2018.1469660

Nikitina, L., Mohd, D. Z., \& Cheong, S. L. (2016). Construction and validation of a questionnaire on language learning motivation. Zbornik Instituta za pedagoska istrazivanja, 48(2), 284-300. https://doi.org/10.2298/ZIPI1602284N

Nofal, M. Y., \& Dweik, B. S. (2011). The language situation among the Indians of Yemen: A sociolinguistic study [Unpublished master's thesis]. Middle East University. 
Nosheen, S. S., Javed, M., \& Akhtar, H. (2020). Analyzing Strategies for Developing Students Speaking Skills in Public Universities of Pakistan. Global Regional Review, 1, 92-99.

Pamuk, S., Ergun, M., Cakir, R., Yilmaz, H. B., \& Ayas, C. (2015). Exploring relationships among TPACK components and development of the TPACK instrument. Education and Information Technologies, 20(2), 241-263.

Panhwar, A. H., Baloch, S., \& Khan, S. (2017). Making communicative language teaching work in Pakistan. International Journal of English Linguistics, 7(3), 226-234.

Peng, J. (2013). The challenge of measuring willingness to communicate in EFL contexts. The Asia-Pacific Education Researcher, 22(3), 281-290.

Peng, J. E., \& Woodrow, L. J. L. I. (2010). Willingness to communicate in English: A model in the Chinese EFL classroom context. Language Learning: A Journal of Research in Language Studies, 60(4), 834-876. https://doi.org/10.1111/j.1467-9922.2010.00576.x

Qawar, H. A. (2014). Language choice and language use in an Arab Canadian multilingual community (Quebec-Canada): A sociolinguistic study. [Unpublished master's thesis]. Middle East University.

Rassool, N. (2013). The political economy of English language and development: English vs. national and local languages in developing countries. In E. J. Earling \& P. Seargeant (Eds.), English and development: Policy, pedagogy and globalization, (pp. 45-68). Multilingual Matters.

Riasati, M. J., \& Rahimi, F. (2018). Situational and individual factors engendering willingness to speak English in foreign language classrooms. Cogent Education, 5(1), 1-15. https://doi.org/10.1080/2331186X.2018.1513313

Robinson, J. (2010). Triandis' theory of interpersonal behaviour in understanding software piracy behaviour in the South African context. [Unpublished master's thesis]. University of the Witwatersrand Johannesburg.

Shamim, F. (2011). English as the language for development in Pakistan: Issues, challenges and possible solutions. Dreams and realities: Developing countries and the English language, 14(1), 291-310.

Syed, H. A. S. (2016). Dynamics of variables underlying willingness to communicate (WTC) in English (L2): A case study of postgraduate business students at a university classroom in Sukkur, Pakistan [Unpublished doctoral dissertation]. University of York.

Taherdoost, H. (2016). Validity and reliability of the research instrument; how to test the validation of a questionnaire/survey in a research. How to test the validation of a questionnaire/survey in a research (August 10, 2016).

Tamim, T. (2014). The politics of languages in education: issues of access, social participation and inequality in the multilingual context of Pakistan. British Educational Research Journal, 40(2), 280-299.

test the validation of a questionnaire/survey in a research. International Journal of Academic Research in Management, 5(3), 28-36.

Vaezi, Z. (2008). Language learning motivation among Iranian undergraduate students. World Applied Sciences Journal, 5(1), 54-61.

Weaver, C. (2005). Using the Rasch model to develop a measure of second language 
learners' willingness to communicate within a language classroom. Journal of Applied Measurement, 6(4), 396-415.

Yashima, T. (2002). Willingness to communicate in a second language: The Japanese EFL context. The Modern Language Journal, 86(1), 54-66.

Yashima, T. (2002). Willingness to communicate in a second language: The Japanese EFL context. The Modern Language Journal, 86(1), 54-66.

Yashima, T., Zenuk-Nishide, L., \& Shimizu, K. (2004). The influence of attitudes and affect on willingness to communicate and second language communication. Language Learning, 54(1), 119-152. https://doi.org/10.1111/j.14679922.2004.00250.x

Zikmund, W. G., Babin, B., Carr, J., \& Griffin, M. (2003). Business research methods (7th ed.). Thompson Learning. 